\begin{tabular}{|c|c|}
\hline & $\begin{array}{r}\text { ABSYARA: Jurnal Pengabdian Pada Masyarakat } \\
\text { Vol. 2, No. 2, Desember } 2021 \\
\text { Hal. } 301-310\end{array}$ \\
\hline 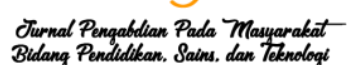 & e-ISSN: $2723-6269$ \\
\hline
\end{tabular}

\title{
Gerakan Informatika Cerdas Berliterasi "Berinovasi Membangun Peradaban diEra 4.0 dengan Budaya Literasi"
}

\author{
Kholida Ismatulloh ${ }^{1}$, Jamaluddin ${ }^{2}$, Baiq Desi Dwi Arianti ${ }^{3}$, Rasyid Hardi Wirasasmita ${ }^{4}$, \\ Yosi Nur Kholisho ${ }^{5}$, M. Zamroni Uska ${ }^{6}$, Heri Kuswanto ${ }^{7}$, Ahmad Fathoni ${ }^{8}$, Samsul \\ Lutfi $^{9}$ \\ Kholida.ebtaryadi@gmail.com*1,yosink.peninfo@gmail.com ${ }^{3}$, ariantibaiq@ hamzanwadi.ac.id $^{4}$, \\ rasyidhw.p.informatika@gmail.com ${ }^{5}$ \\ 1,2,3,4,5,6,7,8,9 Pendidikan Informatika, FMIPA, Universitas Hamzanwadi
}

Received: 01 November 2021 Accepted: 14 December 2021 Online Published: 30 December 2021

DOI: 10.29408/ab.v2i2.433

\begin{abstract}
Abstrak: Kemampuan literasi adalah bagaimana membelajarkan siswa agar rajin membaca dan menulis. Dalam hal ini maka diperlukan kreativitas guru dalam menentukan cara yang efektif dan efisien. Sekolah dasar menjadi dasar pembelajaran literasi karena sekolah dasar merupakan awal seorang anak belajar membaca dan menulis. Dikarenakan situasi seperti saat ini masih dalam kondisi Covid-19 maka para siswa belum bisa belajar ke sekolah secara efektif dan teratur, proses belajar-mengajar dilaksanakan secara daring dan siswa diminta harus paham mengenai penggunaan teknologi informasi seperti hanphone android. Itulah sebabnya para mahasiswa tergerak hatinya untuk memberikan pengajaran dengan meningkatkan budaya literasi siswa dengan bantuan teknologi sebagai media pendukung pembelajarannya, tanpa harus melupakan pentingnya membaca dan menulis dari buku pelajaran mereka. Kegiatan yang dihasilkan berupa kegiatan literasi digital dan belajar sambal bermain dimana para siswa bertugas untuk saling menyambung informasi kepada anggota kelompoknya. Hasil yang didapatkan para siswa menjadi lebih bersemangat dan berminat dalam belajar seperti membaca dan menulis pelajaran karena disampaikan secara menarik pada tampilan media dan video pembelajaran.
\end{abstract}

Kata kunci: Budaya Literasi; Pembelajaran; Teknologi Informasi

\begin{abstract}
Literacy ability teaches students to be diligent in reading and writing. In this case, teacher creativity is needed in determining effective and efficient ways. Elementary school is the basis for learning literacy because elementary school is the beginning of a child learning to read and write. Due to the current situation of Covid-19, students have not been able to study at school effectively and regularly. The teaching-learning process is carried out online, and students are asked to understand the use of information technology such as Android cell phones. The students moved to provide teaching by increasing the literacy culture of students with the help of technology as a medium to support their learning, without having to forget the importance of reading and writing from their textbooks. The resulting activities are digital literacy activities and learning while playing, where students are tasked with connecting information to their group members. The results obtained by the students became more enthusiastic and interested in learning such as reading and writing lessons because they were presented attractively on the display of media and learning videos.
\end{abstract}

Keywords: Information Technology; Literacy Culture; Learning 
Ismatulloh, K., Jamaluddin, J., Arianti, B. D. D, Wirasasmita, R. H., Kholisho, Y. K., Uska, M. Z., Kuswanto, H., Fathoni, A., Lutfi, S. (2021). Gerakan Informatika Cerdas Berliterasi "berinovasi membangun peradaban diera 4.0 dengan budaya literasi". ABSYARA: Jurnal Pengabdian Pada Masyarakat, 2(2), 301-310. doi:10.29408/ab.v2i2.4333

\section{PENDAHULUAN}

Kementerian Pendidikan dan Kebudayaan (2013) memaparkan bahwa pengembangan kurikulum 2013 diharapkan dapat menghasilkan insan Indonesia yang produktif, kreatif inovatif dan afektif melalui penguatan sikap (tahu mengapa), keterampilan (tahu bagaimana) dan pengetahuan (tahu apa) yang terintegrasi. Akan tetapi masih banyak permasalahan yang dihadapi oleh pendidikan, salah satunya adalah rendahnya minat membaca peserta didik.

Salah satu upaya yang dilakukan oleh pemerintah untuk meningkatkan minat baca siswasiswi, pada tahun 2013 Kementerian Pendidikan dan Kebudayaan melalui Peraturan Menteri Nomor 23 tahun 2013 merencanakan sebuah Gerakan literasi sekolah untuk membantu siswa menumbuh kembangkan budaya membaca dan menulis siswa di lingkungan sekolah.

Melalui Gerakan literasi sekolah siswa juga perlu melek akan teknologi dan komunikasi yang semakin hari semakin berkembang pesat. Teknologi informasi juga dapat mempermudah proses pembelajaran di sekolah apalagi yang sebagai sasarannya adalah siswa- siswi TK/ SD/ SMP yang mana tim pengajar harus variatif dalam menyampaikan pembelajaran di sekolah agar mereka tidak cepat jenuh bahkan bosan.

Era Industri 4.0 atau yang biasa dikenal dengan revolusi industri 4.0 merupakan perkembangan bidang industri, dapat dilihat dari kemajuan dan pemanfaatan teknologi informasi yang kian berkembang guna menjadikan bidang industri lebih modern, efektif dan efisien. Kemajuan teknologi informasi pada era industri 4.0 tidak hanya berkembang untuk bidang industri saja melainkan pemerintahan, bidang pendidikan, kesehatan, dan lain-lain juga ikut memanfaatkan teknologi informasi tersebut dan tidak dapat dipisahkan dari kehidupan manusia (Kholisho \& Lutfi, 2020). Salah satunya dalam bidang pendidikan munculnya media-media pembelajaran online baik dalam bentuk aplikasi maupun yang dijabarkan pada website pembelajaran menjadi bukti bahwasanya dunia pendidikan juga mengalami kemajuan dalam penerapan teknologi informasi (Rosita, 2021; Rasmila, dkk., 2021). Aplikasi pembelajaran melahirkan banyak terobosan baru dalam meningkatkan efisiensi dan efektivitas proses pembelajaran (Wirasasmita, dkk., 2020; Fitria, dkk., 2021).

Dalam lingkup masyarakat kesadaran akan potensi dan pemanfaatan bahan- bahan yang di sekitarnya sebenarnya memiliki nilai bila dikelola dan dimanfaatkan dengan benar, hal ini tentunya juga memberikan peluang bagi masyarakat untuk mencoba dan belajar pemanfaatan benda- benda yang ada di sekitarnya, sehingga semakin meningkatkan potensi dan kualitas diri guna membantu memajukan daerah. Kurangnya pemahaman tentang pentingnya literasi dalam kehidupan khususnya dalam lingkup pendidikan juga merupakan salah satu faktor pendorong kegiatan ini dilaksanakan, dengan semakin baik kita mengenal literasi maka akan semakin menambah wawasan guna untuk meningkatkan kualitas diri lebih baik kedepannya.

Berdasarkan pemaparan permasalahan yang ada di atas maka dilakukanlah kegiatan Informatika Cerdas Berliterasi dengan berkolaborasi dengan kegiatan mahasiswa/ mahasiswi HMPS Pendidikan Informatika. Kegiatan ini bertujuan untuk meningkatkan minat siswa siswi dalam perkembangan teknologi guna membantu proses pembelajaran TIK di sekolah. 
Ismatulloh, K., Jamaluddin, J., Arianti, B. D. D, Wirasasmita, R. H., Kholisho, Y. K., Uska, M. Z., Kuswanto, H., Fathoni, A., Lutfi, S. (2021). Gerakan Informatika Cerdas Berliterasi "berinovasi membangun peradaban diera 4.0 dengan budaya literasi". ABSYARA: Jurnal Pengabdian Pada Masyarakat, 2(2), 301-310. doi:10.29408/ab.v2i2.4333

\section{METODE PELAKSANAAN}

\section{Waktu dan Lokasi}

Kegiatan pengabdian kepada masyarakat ini dilakukan dari tanggal 2 Oktober 2021. Kegiatan pengabdian kepada masyarakat ini diikuti oleh 20 siswa/siswi dari beberapa jenjang PAUD/TK, SD/MI, MTs/SMP yang bertempat di TBM Pojok Nusantara, Desa Pringga Jurang Utara.

\section{Prosedur pelaksanaan}

Tahapan pelaksanaan kegiatan pengabdian kepada masyarakat dilaksanakan secara langsung ke lokasi basecamp anak- anak belajar di desa Pringga Jurang utara yang dilaksanakan satu hari full pada tanggal 2 Oktober 2021, kegiatan ini melibatkan anggota HMPS program Studi Pendidikan Informatika sebagai tim pengajar dan dosen pendidikan Informatika sebagai penanggung jawab yang memfasilitasi kegiatan tersebut. Kegiatan pengabdian kepada masyarakat ini menggunakan metode:

1. Demonstrasi

Pada tahap ini, dilakukan proses penjelasan dan mendemonstrasikan literasi digital dengan aplikasi yang menayangkan video animasi yang dirancang semenarik mungkin untuk meningkatkan minat belajar para anak- anak di desa setempat agar merasa senang dan terpacu dalam proses belajar.

2. Praktik

Pada tahap praktik, dilakukan secara langsung setelah dilakukan demonstrasi oleh tutor, sehingga apabila ditemukan kesulitan yang terjadi dapat langsung diatasi dan ditindaklanjuti agar supaya semua anak- anak benar- benar paham dan mengerti mengenai pelajaran yang diberikan. Pada kasus praktik tutor memberikan alat sederhana untuk diselesaikan tepat waktu sesuai dengan perintah yang telah disepakati sebelumnya.

3. Game (permainan)

Tahap terakhir yakni Game (permainan) dimana masing-masing anak akan ada perwakilan lalu diberikan soal dengan cara dibisiki oleh salah seorang tutor pengajar lalu akan diteruskan ke teman- teman kelompoknya.

\section{HASIL DAN PEMBAHASAN}

\section{HASIL}

Berdasarkan dari hasil permasalahan yang di telah dipaparkan ditemukan berbagai masalah yakni selama pembelajaran yang berlangsung saat ini kurang lebih hampir 2 tahun lamanya mengakibatkan proses belajar mengajar mereka lebih banyak daring daripada luring (langsung) sehingga mengakibatkan anak-anak cenderung lebih banyak bermain HP yang mengakibatkan intensitas belajar ke sekolah berkurang dikarenakan Covid 19. Kasus Covid 19 ini juga mengakibatkan banyak anak- anak jadi putus sekolah dikarenakan orang tua mereka tidak sanggup membeli HP android bahkan kuota internet, dikarenakan pekerjaan orang tua mereka sebagian besar sebagai petani atau pekerja harian. Hal tersebutlah yang mendasari para mahasiswa kami di program studi Pendidikan Informatika tergerak hatinya untuk mengadakan pelatihan pengajaran literasi kepada anak- anak khususnya di desa Pringga Jurang utara guna 
Ismatulloh, K., Jamaluddin, J., Arianti, B. D. D, Wirasasmita, R. H., Kholisho, Y. K., Uska, M. Z., Kuswanto, H., Fathoni, A., Lutfi, S. (2021). Gerakan Informatika Cerdas Berliterasi "berinovasi membangun peradaban diera 4.0 dengan budaya literasi". ABSYARA: Jurnal Pengabdian Pada Masyarakat, 2(2), 301-310. doi:10.29408/ab.v2i2.4333

membantu peningkatan pendidikan di Indonesia. Solusi yang diberikan guna untuk meningkatkan pendidikan di desa Pringga Jurang utara diuraikan sebagai berikut:

Tabel 1. Uraian pelaksanaan kegiatan PKM

\begin{tabular}{|c|c|c|c|c|}
\hline No. & $\begin{array}{l}\text { Uraian } \\
\text { Kegiatan }\end{array}$ & Model & Implementasi & Hasil \\
\hline 1. & $\begin{array}{l}\text { Literasi } \\
\text { Digital }\end{array}$ & $\begin{array}{l}\text { - Video } \\
\text { Animasi } \\
\text { - Q\&A } \\
\text { (Question } \\
\text { and } \\
\text { Answer) }\end{array}$ & $\begin{array}{l}\text { - Menayangkan } \\
\text { animasi } \\
\text { tentang } \\
\text { Smartphone } \\
\text { dan Internet } \\
\\
\text { - Memberikan } \\
\text { Soal } \\
\text { Interaktif } \\
\text { yang di } \\
\text { berikan } \\
\text { Berdasarkan } \\
\text { Penayangan } \\
\text { Video } \\
\text { Animasi }\end{array}$ & $\begin{array}{l}\text { - Seluruh peserta literasi dari jenjang TK/SD/SMP } \\
\text { menjadi paham dengan animasi- animasi yang } \\
\text { ada pada smartphone dan internet, dan } \\
\text { mengetahui fungsi dari keberadaan animasi pada } \\
\text { smartphone dan internet tersebut dalam } \\
\text { pembelajaran. } \\
\text { Pada saat soal interaktif di berikan peserta di } \\
\text { masing- masing jenjang ternyata } 70 \% \text { dari } \\
\text { jumlah keseluruhan memahami dan bisa } \\
\text { mengaplikasikannya fungsi dan kegunaannya } \\
\text { secara baik. }\end{array}$ \\
\hline 2. & $\begin{array}{l}\text { Game } \\
\text { Didik } 1\end{array}$ & $\begin{array}{l}\text { Game Bisik } \\
\text { Kalimat } 1\end{array}$ & $\begin{array}{l}\text { - Menampilkan } \\
\text { media belajar } \\
\text { - Game Tim } \\
\text { Menampilkan } \\
\text { Game seputar } \\
\text { Komponen } \\
\text { Komputer }\end{array}$ & $\begin{array}{l}\text { - } 40 \text { orang siswa dari keseluruhan jenjang dibagi } \\
\text { ke masing-masing jenjang untuk bermain Game } \\
\text { bisik } 1 \text { dan } 20 \text { anak TK (jumlah total) dan } 10 \text { anak } \\
\text { SD (jumlah total) merasa nyaman dan asyik } \\
\text { dalam Game media belajar yang penuh dengan } \\
\text { animasi menarik. } \\
20 \text { anak SMP yang menjadi peserta literasi } \\
\text { mampu dan paham membedakan komponen- } \\
\text { komponen pembentuk komputer walaupun } \\
\text { persediaan fasilitas yang kurang maksimal. }\end{array}$ \\
\hline 3 & $\begin{array}{l}\text { Teknologi } \\
\text { Informasi }\end{array}$ & $\begin{array}{l}\text { - Pengenalan } \\
\text { Komputer } \\
\text {-Pengenalan } \\
\text { Media Sosial }\end{array}$ & $\begin{array}{l}\text { Peserta } \\
\text { mampu } \\
\text { mengetahui } \\
\text { perangkat } \\
\text { Komuter }\end{array}$ & $\begin{array}{l}\text { - Pada pembahasan ini di khususkan untuk jenjang } \\
\text { SMP yang berjumlah } 20 \text { orang dimana dari } 20 \\
\text { orang anak hanya } 3 \text { orang yang masih sering } \\
\text { keliru bahkan tertukar dengan fungsi perangkat } \\
\text { komputer dikarenakan mereka masih sangat } \\
\text { jarang bahkan tidak pernah melihat perangkat } \\
\text { komputer secara langsung. } \\
\text { - Namun pada saat pembahasan sosial media } 100 \% \\
\text { dari jumlah anak- anak SMP langsung paham } \\
\text { bahkan mengerti kegunaan fitur- fitur pada } \\
\text { aplikasinya. }\end{array}$ \\
\hline 4 & $\begin{array}{l}\text { Game } \\
\text { Didik } 1\end{array}$ & Game Karet & $\begin{array}{l}\text { Menampilkan } \\
\text { Game yang } \\
\text { bertujuan } \\
\text { untuk melatih } \\
\text { kemampuan } \\
\text { antar Tim. }\end{array}$ & $\begin{array}{l}\text { - Jenjang TK (10 orang) dibuat menjadi } 2 \\
\text { kelompok, jenjang SD (10 orang) menjadi } 2 \\
\text { kelompok, dan jenjang SMP (20 orang) menjadi } \\
4 \text { kelompok. } \\
\text { - Masing-masing jenjang diberikan permasalahan } \\
\text { yang sesuai dengan jenjangnya masing-masing } \\
\text { dan ternyata kekompakan dan keseruan TIM }\end{array}$ \\
\hline
\end{tabular}


terjadi di jenjang SD. 2 kelompok bisa menyelesaikan Game karetnya tepat waktu dan menjawab benar.

- Jenjang TK masih larut dengan kata Game sehingga dalam setiap permainan banyak di antara mereka larut dengan keasyikan sendiri atau yang lainnya.

- Sedangkan pada jenjang SMP sudah mulai saling menyalahkan satu dengan yang lain pada anggota timnya dalam memecahkan masalah atau pertanyaan yang diberikan.

- Kegiatan terakhir pemberian hadiah kepada semua peserta literasi di berbagai jenjang yang berjumlah 40 orang.

- Penutupan.

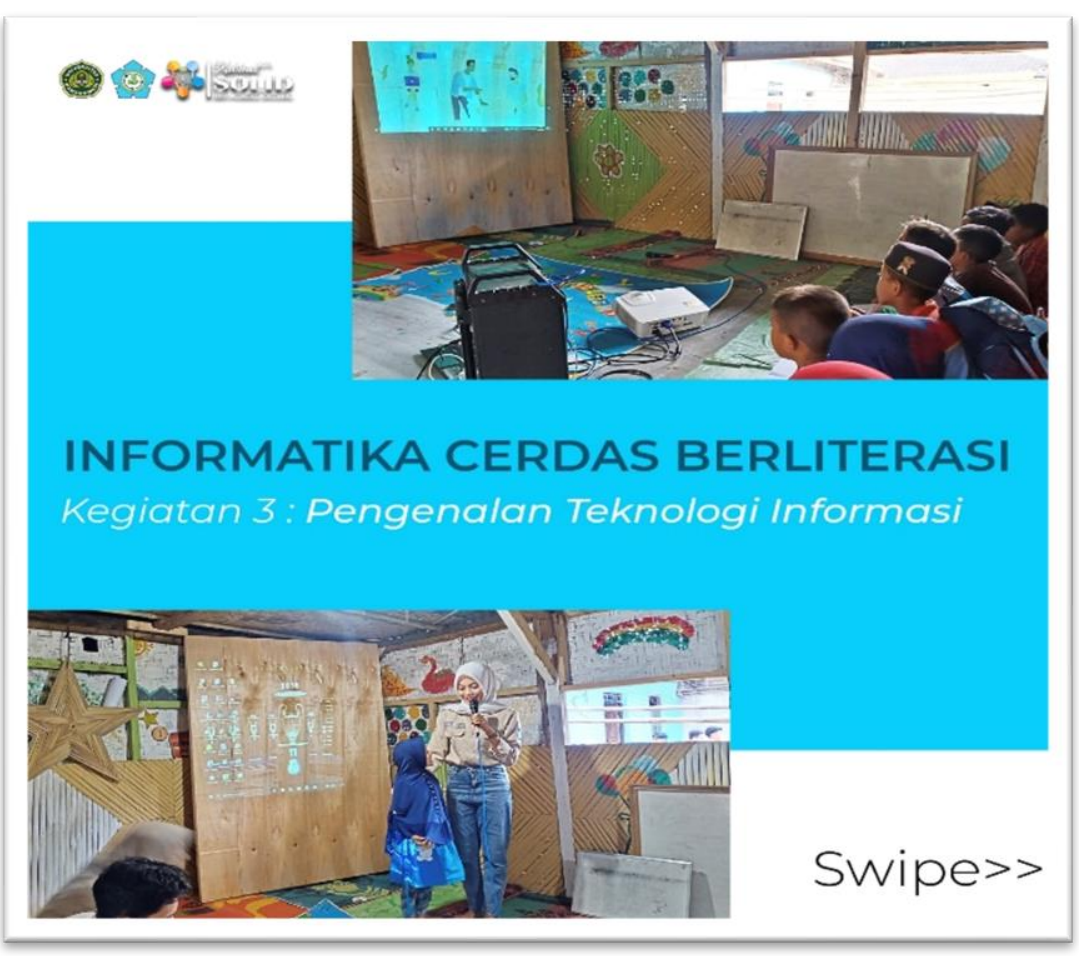

Gambar 1. Proses Pengenalan Teknologi Informasi 


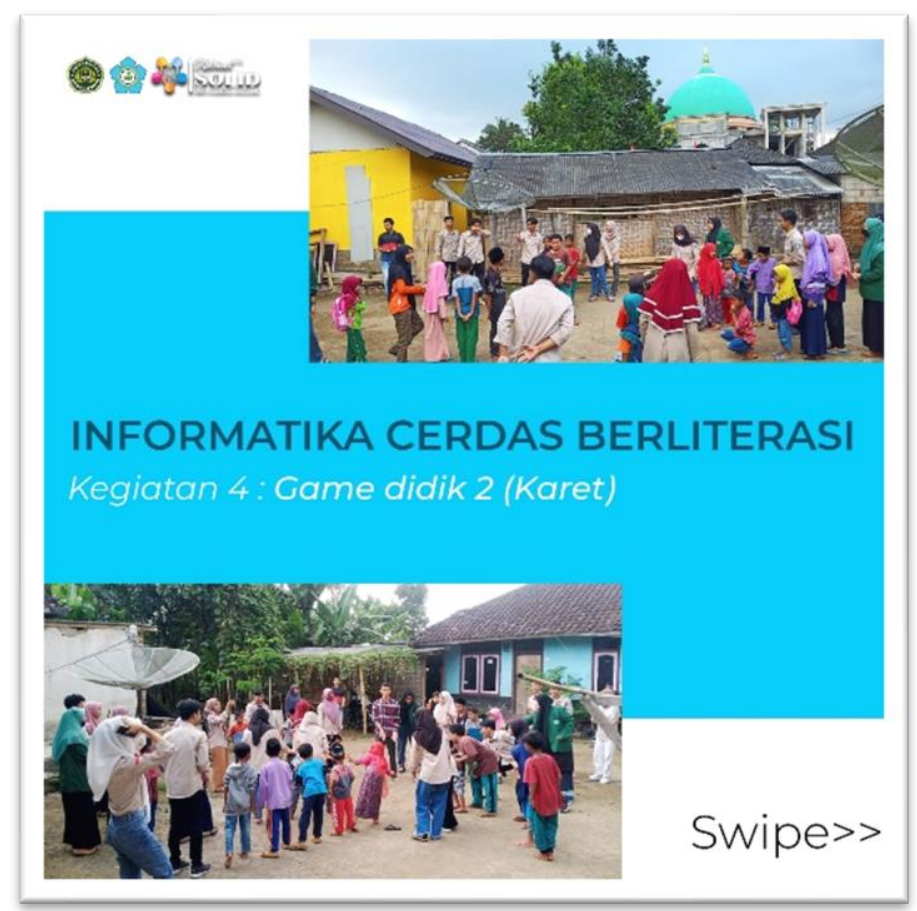

Gambar 2. Proses Game Didik (Karet)

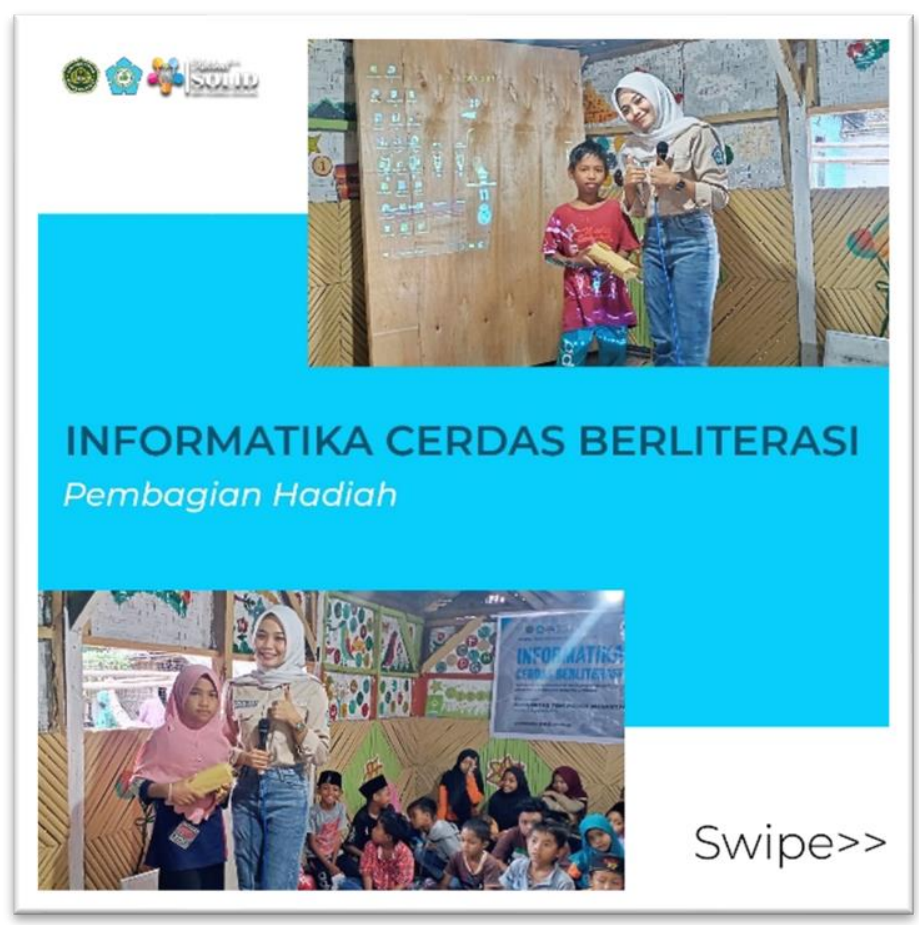

Gambar 3. Proses Pembagian Hadiah

\section{PEMBAHASAN}

Literasi adalah kemampuan dasar yang harus dimiliki oleh peserta didik sedari dini, yaitu anak yang memiliki rentang usia 0- 6 tahun. Usia ini memiliki ciri khas dalam perubahan tingkah laku. Anak usia dini merupakan kelompok usia yang berada dalam proses pertumbuhan dan perkembangan yang bisa disebut dengan masa Golden Age (Suyadi dalam Nahdi \& 
Yunitasari, 2020). Menurut Meliantina (2019), dalam pelaksanaan program literasi sekolah semua guru memiliki peranannya masing-masing dalam kaitannya dengan kegiatan literasi tujuannya untuk membiasakan membaca pada peserta didik yang diharapkan melalui proses membaca dapat menumbuhkan karakter gemar membaca, yang tentunya penumbuhan karakter ini tidak melalui proses yang cepat namun membutuhkan waktu yang tidak singkat.

Musfiroh dalam Hasanah \& Deiniatur (2019) minat membaca dan menulis dapat dirangsang melalui berbagai cara, terutama pajanan buku-buku cerita bergambar dan pemanfaatannya. Di berbagai sudut tempat, pajangan buku cerita bergambar dapat berfungsi optimal karena guru secara rutin membacakan cerita dan menerima tawaran anak untuk membacakan buku. Dengan demikian, merangsang minat membaca dan menulis juga dilakukan terhadap pemajanan tulisan pada benda-benda yang dipakai anak, seperti loker, daftar nama dan kontainer anak. Budaya literasi memiliki hambatan-hambatan ketika diterapkan pada anak diantaranya: 1 . Kebiasaan literasi di lingkungan keluarga belum menjadi prioritas utama, terkadang kegiatan membaca dimulai dengan paksaan hanya sekedar pemenuhan kewajiban semata bukan sebagai sarana hiburan yang menyenangkan dari setiap individu, 2. Kurangnya buku bacaan/sumber bacaan yang tersedia, 3. Lingkungan yang tidak mendukung terhadap pembiasaan membaca, dan 4. Literasi merupakan kegiatan yang membutuhkan konsentrasi dan tidak bisa dilakukan dengan kegiatan lain dalam waktu yang bersamaan karena akan berpengaruh pada tingkat pemahaman pembaca.

"Pada dasarnya kemampuan literasi adalah bagaimana membelajarkan siswa agar rajin membaca dan menulis. Dalam hal ini maka diperlukan kreativitas guru dalam menentukan cara yang efektif dan efisien (Widodo, 2015)." Sesuai dengan pendapat (Sutrianto, dkk., 2016) Menyatakan Literasi Sekolah dalam konteks GLS adalah ' kemampuan mengakses, memahami, dan menggunakan sesuatu secara cerdas melalui berbagai aktivitas, antara lain membaca, melihat, menyimak, menulis, dan/ atau berbicara'. Sejalan dengan (Yunus, dkk., 2017) yang menyatakan literasi adalah kemampuan membaca, menulis, berbicara dan menyimak.

"Kemampuan berbahasa Indonesia, termasuk keterampilan literasi perlu mendapatkan penekanan dalam kompetensi, pemilihan materi dan distribusinya di sekolah dasar maupun sekolah menengah. Sekolah dasar menjadi dasar pembelajaran literasi karena sekolah dasar merupakan awal seorang anak belajar membaca dan menulis (Nurdiyanti, dkk., 2010)." Di desa Pringga Jurang Utara penerapan literasi belum diterapkan secara maksimal itulah sebabnya mahasiswa kami berkeinginan untuk memupuk budaya literasi anak- anak untuk terbiasa dengan budaya membaca yang dikolaborasikan dengan penggunaan teknologi internet dimana penggunaan teknologi internet dapat mempercepat keinginan bahkan ketertarikan anak- anak dalam belajar apalagi dalam kegiatan tersebut diselingi dengan berbagai macam permainan yang mengasyikkan.

Pelatihan literasi yang dilakukan oleh mahasiswa yang terkumpul dalam HMPS Pendidikan Informatika bertujuan untuk meningkatkan minat dan budaya literasi sejak dini dari jenjang PAUD/TK, SD/MI, Mts/SMP guna untuk membangun peradaban di era 4.0. Kegiatan ini sengaja dilaksanakan untuk menumbuhkan budaya literasi di jenjang PAUD/TK, SD/MI, Mts/SMP apalagi dalam kondisi pandemi Covid 19 seperti saat ini, yang mana para anak- anak jenjang peralihan tersebut lebih banyak memanfaatkan teknologi smartphone android dengan bermain sosial media dan Game sehingga pemanfaatan buku sebagai bahan bacaan semakin 
kurang peminatnya. Kegiatan mahasiswa HMPS Pendidikan Informatika kali ini mengitari daerah Pringga Jurang Utara di suatu desa pedalaman dari sana mereka mendapatkan suatu organisasi giat belajar yang sudah berlabel legal namun tidak berjalan maksimal sejak pandemi Covid 19 yang berjumlah 40 orang dari berbagai jenjang PAUD/TK, SD/MI, Mts/SMP. Dari sanalah maka para mahasiswa berkeinginan mengajarkan budaya literasi berbasis teknologi dan Game pada mereka. Mereka pun langsung menyambut kedatangan mahasiswa dengan sangat suka cita dikarenakan para mahasiswa menyediakan berbagai fasilitas teknologi yang jarang mereka lihat bahkan gunakan dalam proses belajar- mengajar di sekolah.

Di awal kegiatan para mahasiswa memberikan pengarahan dan pengenalan mengenai literasi digital kepada peserta literasi yang sudah dibagi- bagi sesuai dengan jenjangnya masing-masing. Dalam pelatihan yang dilakukan full day selama sehari benar- benar dimanfaatkan dan digunakan sebaik mungkin oleh para mahasiswa untuk melatih, mengajar, dan menyediakan permainan di sela- sela kegiatan. 40 orang peserta sangat antusias dan tertarik dengan pemaparan materi yang disajikan, walaupun ada beberapa yang lebih memperhatikan fasilitas- fasilitas yang digunakan pada saat mengajar namun tidak mengganggu proses pembelajaran literasi. Kegiatan pun berjalan sesuai harapan bahkan para peserta menginginkan kegiatan dipaksakan lebih dari sehari atau berkelanjutan.

Susanto (2013:63) menyatakan bahwa perkembangan minat sangat tergantung pada lingkungan dan orang-orang dewasa yang erat pergaulannya dengan mereka, sehingga secara langsung akan berpengaruh pula terhadap kematangan psikologisnya. Anak- anak di desa Pringga Jurang Utara dorongan untuk meningkatkan budaya literasi belum diterapkan secara maksimal, terlihat dari minat anak- anak dalam membaca dan menulis kurang sehingga para tutor mempersiapkan berbagai media berupa video untuk bisa membantu menumbuhkan minat baca pada anak- anak.

Dengan alat bantu video dan media pembelajaran yang telah disiapkan untuk mengajar di lokasi ternyata sangat membantu sekali menumbuhkan budaya berliterasi anak- anak setempat, dimana kegiatan tersebut dibungkus dengan berbagai macam kegiatan menarik seperti pelatihan video literasi digital, pembelajaran teknologi mendasar, dan Game (permainan). Ternyata hal utama yang bisa meningkatkan budaya berliterasi apalagi di desa yang mana anak- anaknya masih tergolong awam mengenal teknologi adalah dengan kunjungan atau pelatihan- pelatihan secara langsung ke lokasi dengan menampilkan bahan ajar yang dirangkaikan dengan video pembelajaran berbasis digital dan permainan- permainan yang menarik.

\section{Faktor penghambat penerapan Literasi di desa Pringga Jurang Utara}

Faktor penghambat literasi anak- anak di desa Pringga Jurang Utara

1. Sebagian dari kegiatan yang sudah di rencanakan tidak berjalan dengan lancar karena terkendala dengan listrik yang mati khususnya pada kegiatan Literasi Digital, sehingga menyebabkan pelaksaan kegiatan jadi terjeda dan waktu selesainya jadi molor.

2. Pembagian tugas dan disiplin para tutor masih kurang, sehingga beberapa program kurang maksimal.

3. Cuaca yang tidak kondusif juga memiliki dampak terhadap kegiatan Informatika Cerdas Berliterasi, karena kebetulan pada saat kegiatan berlangsung cuaca mendung 
disertai hujan yang mengakibatkan sebagian dari anak- anak tidak diberikan izin oleh orang tuanya mengikuti kegiatan tersebut.

Beberapa faktor penghambat diatasi sempat membuat kegiatan molor beberapa jam dikarenakan mobilisasi ke lokasi terhambat dikarenakan medan ke lokasi yang kurang baik karena daerah tersebut merupakan dataran tinggi, bersuhu dingin, dan sudah mulai musim penghujan. Namun walaupun begitu proses kegiatan tetap berjalan lancar dan sesuai dengan rencana dan tujuan awal yakni mencerdaskan dan menumbuhkan budaya berliterasi anak- anak di desa Pringga Jurang Utara Lombok Timur di Era 4.0.

\section{SIMPULAN}

Program kegiatan pelatihan pengajaran literasi dapat meningkatkan minat dan motivasi anak- anak dalam bidang Pendidikan apalagi pada saat ini masa pandemi yang mana sekolahsekolah tidak bisa melaksanakan kegiatan belajar- mengajar dengan maksimal selama 6 hari seperti sebelumnya. Kegiatan ini membantu para anak- anak dari jenjang TK/ SD/ SMP di desa Pringga Jurang Utara membuka wawasan untuk berliterasi yang dibungkus secara teknologi guna menarik perhatian dan menghindari kebosanan pada proses belajar. Segala sesuatu yang dibungkus dengan teknologi pada saat ini sangat cepat sekali mengalami peningkatan maka dari itu para mahasiswa dan dosen melakukan kegiatan budaya literasi berbasis teknologi di desa- desa yang ada di Lombok Timur.

\section{PERNYATAAN PENULIS}

Artikel ini merupakan hasil program pengabdian kepada masyarakat untuk mendukung pelaksanaan kegiatan HMPS Pendidikan Informatika dan tidak pernah dipublikasikan pada jurnal ilmiah mana pun.

\section{DAFTAR PUSTAKA}

Fitria, R., Ervina, E., Kurniati, K., \& Astafi, R. (2021). Pendampingan peningkatan kemampuan bahasa Inggris siswa panti asuhan Dayang Dermah Bengkalis. ABSYARA: Jurnal Pengabdian Pada Masyarakat, 2(1), 56-61.

Hasanah, U., \& Deiniatur, M. (2019). Membangun Budaya Membaca Pada Anak Usia Dini Di Era Digital. At-Tajdid: Jurnal Pendidikan dan Pemikiran Islam, 3(01), 10-24.

Kementerian Pendidikan dan Kebudayaan RI 2013. Paduan Implementasi kurikulum 2013. Jakarta : Kementerian Pendidikan dan Kebudayaan RI

Kholisho, Y. N., \& Lutfi, S. (2020, May). The Development Of Augmented Reality For Hardware Introduction For SDU Hamzanwadi Students. In Journal of Physics: Conference Series (Vol. 1539, No. 1, p. 012009). IOP Publishing.

Meliantina, M. (2019). Menerapkan Budaya Literasi Guru Sekolah Dalam Upaya Meningkatkan Pendidikan Di Era Industri 4.0. Muróbbî: Jurnal Ilmu Pendidikan, 3(2), 120-139.

Nahdi, K., \& Yunitasari, D. (2019). Literasi Berbahasa Indonesia Usia Prasekolah Ancangan Metode Dia Tampan dalam Membaca Permulaan. Jumal Obsesi: Jumal Pendidikan Anak Usia Dini, 4(1), 446-453. 
Nurdiyanti, E., \& Suryanto, E. (2010). Pembelajaran literasi mata pelajaran bahasa indonesia pada siswa kelas V sekolah dasar. Paedagogia, 13(2).

Rasmila, R., Amalia, R., Jemakmun, J., \& Mukti, A. R. (2021). Pelatihan online internet sehat sebagai media pembelajaran bagi siswa-siswi SMK Nurul Huda Pemulutan Barat. ABSYARA: Jurnal Pengabdian Pada Masyarakat, 2(1), 26-31.

Rosita, F. Y. (2021). Pelatihan jurnalistik pada redaktur majalah sekolah Serambi AlMuayyad. ABSYARA: Jurnal Pengabdian Pada Masyarakat, 2(1), 32-40.

Sumaryanti, L. (2018). Membudayakan Literasi pada Anak Usia Dini dengan Metode Mendongeng. AL-ASASIYYA: Journal Of Basic Education, 3(1), 117-125.

Susanto, Amad. 2013. Teori Belajar dan Pembelajaran di Sekolah Dasar. Jakarta: Kencana Prenada Media Group.

Sutrianto., Rahmawan, Nilam., Hadi, Samsul., Fitriono, Heri. 2016 Panduan Gerakan Literasi Sekolah di Sekolah Menengah Atas. Jakarta: Direktorat Jenderal Pendidikan Dasar dan Menengah Kementerian Pendidikan dan Kebudayaan.

Widodo, S. (2017). Membangun Kelas Literat Berbasis Pendidikan Lingkungan Hidup Untuk Melatihkan Kemampuan Literasi Siswa Di Sekolah Dasar. Prosding Seminar Nasional Pendidikan.

Wirasasmita, R. H., Arianti, B. D. D., Uska, M. Z., Kholisho, Y. N., \& Wardi, Z. (2020). Edukasi Zero Waste berbasis teknologi informasi. ABSYARA: Jurnal Pengabdian Pada Masyarakat, 1(2), 35-42. 